This PDF is a selection from a published volume from the National Bureau of Economic Research

Volume Title: African Successes, Volume II: Human Capital

Volume Author/Editor: Sebastian Edwards, Simon Johnson, and David N. Weil, editors

Volume Publisher: University of Chicago Press

Volume ISBNs: 978-0-226-31605-5 (cloth)

Volume URL: http://www.nber.org/books/afri14-2

Conference Dates: December 11-12, 2009; July 18-20, 2010; August 3-5, 2011

Publication Date: September 2016

Chapter Title: Success in Entrepreneurship: Doing the Math

Chapter Author(s): Michael Kremer, Jonathan Robinson, Olga Rostapshova

Chapter URL: http://www.nber.org/chapters/c13449

Chapter pages in book: (p. $281-303$ ) 


\title{
Success in Entrepreneurship Doing the Math
}

\author{
Michael Kremer, Jonathan Robinson, \\ and Olga Rostapshova
}

\subsection{Introduction}

Outside of agriculture, the family-owned business is the most common form of enterprise in low-income countries. These types of businesses employ hundreds of millions of people (e.g., Banerjee and Duflo 2007; World Bank 2015), yet there is tremendous heterogeneity in how such firms perform. For instance, in the retail sector, some firms hold large inventories and earn significant profits, while others hold minimal stocks and provide little more than subsistence income for their owners. However, it is an open question why there is such heterogeneity in the success of small firms. This chapter examines these issues in the context of one specific industry, retail, in a region of western Kenya.

A companion paper (Kremer, Robinson, and Rostapshova 2013b) calculates bounds on the marginal returns to inventories for a sample of retail firms in western Kenya. The results suggest some firms have high returns to

Michael Kremer is the Gates Professor of Developing Societies in the Department of Economics at Harvard University and a research associate of the National Bureau of Economic Research. Jonathan Robinson is associate professor of economics at the University of California, Santa Cruz, and a research associate of the National Bureau of Economic Research. Olga Rostapshova is a technical director with Social Impact.

We thank Louis Kasekende, David Laibson, Isaac Mbiti, David Weil and participants at various seminars and conferences for helpful comments. Abdullah Al-Sabah, Kenzo Asahi, Pia Basurto, Dan Bjorkegren, Conner Brannen, Elliott Collins, Sefira Fialkoff, Katie Hubner, Eva Kaplan, Anthony Keats, Jamie McCasland, and Russell Weinstein provided excellent research assistance. We gratefully acknowledge funding from the SEVEN Foundation, the Kauffman Foundation, and the NBER Africa program. We thank IPA-Kenya for administrative support. For acknowledgments, sources of research support, and disclosure of the authors' material financial relationships, if any, please see http://www.nber.org/chapters/c13449.ack. 
inventories, but that returns vary greatly across firms. The study leverages administrative data from a wholesaler on whether firms purchased enough to take advantage of quantity discounts. While many orders just qualify for a discount, many others are just below the quantity threshold. In our sample, the median shop misses at least some opportunities to earn rates of return in excess of 100 percent (by increasing one purchase slightly to meet the bulk discount threshold and correspondingly reducing the next purchase). ${ }^{1}$

These results are consistent with a series of papers suggesting that many small firms in developing countries face high returns to capital (e.g., de Mel, McKenzie, and Woodruff 2008; Duflo, Kremer, and Robinson 2011; McKenzie and Woodruff 2008; Fafchamps et al. 2011; Udry and Anagol 2006; Banerjee and Duflo 2012).

This study focuses not on the marginal return to inventory but on the correlates of overall inventory and profit levels. Background data was collected on a large sample of retail shops using detailed surveys on a host of firm and owner characteristics. The survey included vocabulary and reading tests in English and Swahili, a math problem-solving test, a digit-recall memory test, Raven progressive matrices, and a maze completion speed test. The survey included modules on demographics; access to savings and credit; ownership of land, durable goods, and other assets; transfers given and received; income; and financial record keeping and other business practices. Incentivized modules to measure time preferences and small-stakes risk aversion were also administered. To measure time preferences, respondents were asked to choose between several schedules of time-dated cash payouts. To measure small-stakes risk aversion, subjects were asked to divide a portfolio of $100 \mathrm{KSh}$ (approximately \$1.33) between a safe asset and a risky asset that paid zero with 50 percent probability and 2.5 times the amount invested with 50 percent probability.

This chapter examines two main business outcomes: inventory size, and profits. For inventories, several correlates are identified. Firm owners with higher math scores, younger firm owners, and firm owners who are less risk averse over small stakes have larger inventories. Shopkeepers with bank accounts also tend to have somewhat larger inventories.

Consistent with our findings that firms with larger inventories have higher profits, these differences translate into profits as well. Firm owners with higher math scores earn higher profits, even conditional on inventories.

The rest of this chapter is organized as follows. Section 9.2 reviews the

1. We also measure the return to increased investment by surveying shops on a regular basis about "stock outs": lost sales due to insufficient inventory. The average bounds on returns are more modest with this approach - the average shop in our sample would achieve a real rate of return of 33 percent to a marginal increase in inventory per year, and 17.6 percent of shops have returns greater than 50 percent. However, if lost customer goodwill or other sales of complementary goods are significant, this will be a very loose lower bound on the rate of return. We were also able to reject the hypothesis that the marginal rates of return are equal across shops. 
related literature, section 9.3 describes the data, section 9.4 discusses the results, and section 9.5 concludes.

\subsection{Literature Review}

\subsubsection{Personality Characteristics and Entrepreneurship}

This work fits into a broad multidisciplinary literature that aims to identify factors correlated with entrepreneurship entry and success.

Most studies in this field have examined the link between various personality characteristics and the decision to enter entrepreneurship. A number of papers argue that characteristics such as risk and autonomy preferences, innovative orientation, and locus of control predict entrepreneurship. ${ }^{2}$

Hartog, van Praag, and van der Sluis (2010) use the US National Longitudinal Study of Youth to examine the effects of various personal characteristics among entrepreneurs and employees. They find that verbal abilities appear to be more important for employees, while mathematical, technical, and social abilities are more important for entrepreneurs. They also argue that general ability and balance across the various kinds of ability generate higher incomes for entrepreneurs.

Caliendo, Fossen, and Kritikos (2010) find that individuals with intermediate levels of risk tolerance survive longer as entrepreneurs than those with very high or very low levels of risk tolerance. Fairlie and Holleran (2012) find that more risk-tolerant individuals and those with a preference for autonomy benefit more from business training.

A smaller literature has focused on entrepreneurs in developing countries. De Mel, McKenzie, and Woodruff $(2008,2009 a, 2010)$ present a large amount of evidence from a sample of small firms in Sri Lanka. In de Mel, McKenzie, and Woodruff (2010), the authors find evidence that microentrepreneurs in Sri Lanka bear more similarities to wage workers in developed countries than to owners of large firms. ${ }^{3}$ De Mel, McKenzie, and Woodruff (2008) find that capital injections are most beneficial to those that score highest on a Digits Forward memory test and de Mel, McKenzie, and Woodruff (2009a) find that several owner characteristics predict innovation (defined as new or significantly improved product, process, marketing, or organization changes). Predictive characteristics include Raven's test scores, optimism measures, previous experience, and time preferences.

2. For example, see Zhao and Seibert (2006), Blanchflower and Oswald (1998), Rauch and Frese (2007), Caliendo, Fossen, and Kritikos (2010), Evans and Leighton (1989), and Puri and Robinson (2009). See Rauch and Frese (2007) for a meta-analysis of this literature.

3. A meta-review of empirical work in developing countries (Van der Sluis, Van Praag, and Vijverberg 2005) finds that more educated workers are more likely to be in wage employment than in nonfarm entrepreneurship, and find that the effect is stronger for women, and in least developed countries. 


\subsubsection{Returns to Capital, Credit, Business Training, and Microcredit}

A host of recent studies have found extremely high marginal rates of return to capital in developing countries (see, for example, de Mel, McKenzie, and Woodruff 2008; McKenzie and Woodruff 2008; Banerjee and Duflo 2012; Udry and Anagol 2006; Fafchamps et al. 2011). However, such high returns are puzzling; it is unclear why firms cannot realize these returns and why owners of small firms do not accumulate more capital until rates of return fall to a more conventional level, as would be suggested by a standard Euler equation. While a possible explanation would be that credit constraints are binding, this seems unlikely to be the whole story, since the Euler equation would hold even under credit constraints. Relatedly, a number of recent randomized experiments on microfinance have found limited take-up for microcredit loans, at least as currently offered by microfinance providers (Bannerjee, Karlan, and Zinman 2015).

Another explanation for high unrealized returns is that human capital constraints are binding. Most studies of providing standard business training to entrepreneurs find limited effects (see Karlan and Valdivia [2010] in Peru; Giné and Mansuri [2011] in Pakistan; Bruhn and Zia [2011] in Bosnia and Herzegovina; and the standard business training provided in Drexler, Fischer, and Schoar [2014] in the Dominican Republic). Fairlie, Karlan, and Zinman (2015) find similarly small effects of business training among potential entrepreneurs in the United States. By contrast, Drexler, Fischer, and Schoar (2014) find larger effects from "rule of thumb" training in the Dominican Republic, which emphasized basic cash management strategies (such as keeping separate accounts for the business and for personal consumption). Working with much larger firms, Bloom et al. (2013) find that providing basic management consulting to Indian textile firms increases total factor productivity by 18 percent, even though many of the changes implemented were already available to firms. Bruhn, Karlan, and Schoar (2012) also find large effects of management consulting among Mexican firms.

\subsection{Data}

\subsubsection{The Small-Scale Retail Sector in Kenya}

The small-scale retail sector comprises a significant share of economic activity in Kenya, particularly in rural areas. For example, Daniels and Mead (1998) estimate that small and medium enterprises with ten or fewer employees (not including agriculture and mineral extraction industries) comprise 12-14 percent of total Kenyan gross domestic product (GDP), and that a quarter of this contribution comes from the retail trade.

This study focuses on a category of retail shops in western Kenya called 
dukas in Kiswahili. These shops are typically owner operated and are ubiquitous in market centers and small towns in the region. They are often located in clusters, adjacent or in close proximity to several competing shops and retail fast-moving consumer goods (FMCG), or consumer-packaged goods (CPG). The FMCG manufacturing industry is highly concentrated. Manufacturers set retail prices, and a single supplier has a very high market share.

Western Kenya is relatively poor, and people tend to buy a fairly small set of goods. Consequently, shops typically sell a relatively homogeneous set of goods, which include basic household products such as perishable and nonperishable foodstuffs, soaps, detergents, cooking fat, sodas, phone cards, and other household items. The more successful shops tend to stock a wider variety of goods, rarely stock out of items, and purchase sufficiently large quantities to qualify for bulk discounts.

Several features of the industry may make it possible for less productive firms to survive, rather than be driven out by more efficient competitors. First, efficient shopkeepers are typically not able to manage multiple shops in different locations. Whether this is due to labor market frictions, moral hazard with employees, or other factors, such constraints set a limit on the scope of firm operations. Second, since many customers tend to travel a short distance to purchase items, shops face only limited competition. Finally, manufacturers preclude price competition by fixing retail prices.

\subsubsection{Sampling}

Some of the data used in this analysis was collected for a companion paper (Kremer et al. 2013b). Firms were sampled from the administrative records of a large distributor of household goods. From the universe of shops in this database, a sample of 854 shops was identified for surveying, spanning a relatively wide geographical area in western Kenya. ${ }^{4}$ Background surveys were successfully completed with 731 of these shops (85.6 percent) in 2009-2010. The remaining shops were untraceable, mostly because they had closed.

This chapter focuses on the dependent variables of inventory size and profits. The first two measures were collected as part of an end-line survey in our companion paper. Of the 731 firms with baseline data, 486 were sampled for an end-line survey that includes the inventory measures used in this chapter, and which was administered approximately $1.5-2$ years after the baseline surveys (between February and May 2011). Enumerators successfully completed surveys with 380 of these shops (78.1 percent). Approximately halfway through the administration of these surveys, the profit module was added to the questionnaire. Therefore, there is a smaller number of observations for that variable (188).

4. The inclusion criterion was that the shops were close enough for enumerators to be able to travel to the shop to conduct surveys. 
Lastly, survival information on shops was collected when enumerators visited market centers for the end-line survey. The data set contains useable information on 700 of the 731 shops (95.8 percent). Information on the remaining shops, unfortunately, could not be obtained.

\subsubsection{Survey Data}

\section{Background Surveys}

The background survey gathered information on a number of standard demographic measures such as the owner's age, sex, ethnicity, educational attainment, literacy, the size of the owner's family, and how long the shop had been open. The survey also included questions on the shop owner's access to and use of savings and credit; self-reported credit constraints; land, durable goods, and other asset holdings; and other sources of income.

In addition, survey instruments included tests of cognitive ability and various psychological measures, including time and risk preferences, as well as attitudes toward entrepreneurship. Established cognitive tests were adapted to the local context to measure language and math ability, memory, and general reasoning ability. Specifically, the survey included vocabulary and reading tests in English and Swahili, a math problem-solving test, Wechsler Memory Scale Digits Forward test, Raven progressive matrices, and a maze completion speed test. For the analysis, the results of several of these variables were aggregated for the cases where there was substantial correlation (for example, measures of vocabulary and language, as well as competency in English and in Swahili).

This chapter focuses specifically on the math test results. This test was adapted from standard psychometric and personnel IQ tests, including the Wonderlic Test and Cognitive Reflection Test and included eleven questions that ranged from simple math calculations (e.g., "A notebook costs $21 \mathrm{KSh}$ for each one. What will four notebooks cost?"), to more challenging analytical reasoning questions (e.g., "In a lake, there is a patch of water hyacinths. Every day, the patch doubles in size. If it takes 48 days for the patch to cover the entire lake, how long would it take for the patch to cover half of the lake?"). The questions used in this analysis are included in the appendix.

Time and risk preferences were assessed by asking respondents to make choices over a variety of incentive-compatible choice sets. To incentivize truth telling, one question was randomly chosen at the end of the interview and the corresponding amount was paid to the respondent. To measure small-stakes risk aversion, respondents were asked how much of a given amount of money they would like to put into a risky asset. The money invested in the risky asset was multiplied by 2.5 with 50 percent probability and was completely lost the other half of the time. The remainder of the money was kept with certainty. 
To estimate time preferences, respondents were asked to choose between a given amount of money (40 Kenyan shillings, or about \$0.50) at a particular date and a larger amount one month later. To estimate time consistency, these questions were asked over two time frames: (a) immediately versus one month in the future, and (b) one month in the future versus two months in the future. In the analysis, respondents were coded as being "patient" if they preferred to wait one month for $55 \mathrm{KSh}$ to taking $40 \mathrm{KSh}$ now. In addition, several measures of time consistency were constructed: (a) "timeconsistent" individuals who exhibit the same discount rate in the present as in the future, (b) "present-biased" individuals who are more patient in the future than in the present, (c) "patient now but impatient later" individuals who are more patient in the present than in the future, and (d) people who exhibit the maximal discount rate in both the present and the future (these people prefer $40 \mathrm{KSh}$ earlier to $500 \mathrm{KSh}$ a month later, no matter what the time period is).

Finally, respondents were asked questions related to their entrepreneurial disposition and other attitudinal characteristics. Questions developed by the World Values Survey were used to the extent possible, and were adapted to the local context.

\section{Inventory and Profit Surveys}

Self-reported profits and inventory were collected between February and May 2011, approximately 1.5-2 years after the background surveys. As shops stock a large number of products, it was too burdensome for the respondents to measure inventories product by product. Respondents were therefore asked to estimate the total value of their inventory (at both wholesale and retail prices) with the enumerator's assistance. In addition, the respondent, together with the enumerator, calculated the value of the thirteen most common items stocked by shops. The methodology to measure profits follows de Mel, McKenzie, and Woodruff (2008). ${ }^{5}$ Respondents were asked to report their income, less expenses and other employee wages, over the previous thirty days. Unfortunately, these questions were included for only a subset of the shops that were surveyed. Therefore, there are only 188 shops with profit data.

The mean value of total inventory was 265,200 KSh (approximately $\$ 3,500)$, more than double of Kenyan per capita GDP, and representing twice the mean value of the durable goods and animals owned by the shopkeepers in our sample. Mean reported monthly profits were 23,900 KSh ( $\$ 320)$. Both the inventory and profit distributions were quite skewed: the median total inventory and median monthly profits were almost half of the means, valued at $\$ 2,000$ and $\$ 160$ respectively. The 75 th percentile was at

5. See de Mel, McKenzie, and Woodruff (2009b) for a discussion of the difficulty in measuring profits, and a justification for using this method. 
$\$ 4,000$ and the 90th at $\$ 9,300$. On the other hand, the 25 th percentile was at $\$ 1,100$. Similar distributions were observed for the inventory calculated using the top thirteen items, as well as for profits.

\section{Firm Survival}

The final outcome measure comes from a census conducted in May 2011 (at the conclusion of the end-line surveys). At that time, enumerators visited every shop from the baseline sample to collect data on whether the firm was still in business at that time. Since collecting this information did not require a survey, it could be obtained for a much larger sample of shops (700). While the enumerators attempted to collect data on the reasons for exits, they were unable to obtain good tracking information for most of the shops that had closed; thus, there is no reliable information on what jobs the shop owners took after exiting. Note that it is difficult to say whether survival of a retail shop is a positive or negative outcome in this setting; it may well be that other, more formal jobs are preferred to small retail employment.

\section{Summary Statistics}

Summary statistics for the 380 shops in the inventory analysis are presented in table 9.1. ${ }^{6}$ The average shopkeeper has 10.8 years of education, substantially more than the typical rural resident in the area, and 97 percent can read and write in Kiswahili. The mean shop has been around for almost 7.5 years, and the average shopkeeper is about thirty-three years old. Fiftysix percent of shopkeepers are male.

Shopkeepers are substantially wealthier than the average rural resident. About 13 percent of owners or their spouses have formal-sector jobs, a figure which is much higher than for the typical rural residents. In addition, 83 percent of shopkeepers in our sample have bank accounts, 42 percent participate in a merry-go-round cooperative (ROSCA), and the average shopkeeper owns 1.95 acres of land. Inventory value and income distributions among shopkeepers are skewed, but even at the 25th percentile shopkeepers have relatively high incomes and wealth in an area where typical agricultural wages are approximately one dollar a day.

Thirty-seven percent of shops report that they would like to borrow money but are unable to do so, while 31 percent keep financial records.

The table also reports information on small-stakes risk aversion. The average shopkeeper invested a bit more than 50 percent into the risky asset. Interestingly, about one-third of the shopkeepers divided money exactly equally between the risky and safe assets, a result which is consistent with workers in the United States who follow the " $1 / \mathrm{n}$ " heuristic of investing in retirement assets (i.e., Benartzi and Thaler 2001, 2007). Since individuals

6. Summary statistics for the larger sample of shops with survival data are presented in table 9A.2. 


\begin{tabular}{|c|c|c|c|c|c|c|}
\hline & \multirow[b]{2}{*}{$\begin{array}{l}\text { Mean } \\
(1)\end{array}$} & \multicolumn{5}{|c|}{ Quantiles } \\
\hline & & $\begin{array}{l}\text { Std. dev. } \\
\text { (2) }\end{array}$ & $\begin{array}{l}25 \text { th } \\
(3)\end{array}$ & $\begin{array}{l}50 \text { th } \\
(4)\end{array}$ & $\begin{array}{l}75 \text { th } \\
(5)\end{array}$ & $\begin{array}{l}90 \text { th } \\
(6)\end{array}$ \\
\hline \multicolumn{7}{|l|}{ Inventories, profits, and credit to customers } \\
\hline Total inventory & 26.52 & 29.67 & 8.00 & 15.00 & 30.00 & 70.00 \\
\hline Inventory in top 13 items & 9.42 & 11.34 & 2.80 & 5.16 & 10.81 & 24.93 \\
\hline Profits in past month & 2.39 & 2.70 & 0.80 & 1.20 & 3.00 & 5.60 \\
\hline Gives out credit to customers & 0.92 & - & - & - & - & - \\
\hline Amount given out in credit in past month & 1.12 & 5.75 & 0.10 & 0.20 & 0.50 & 1.50 \\
\hline \multicolumn{7}{|l|}{ Background characteristics } \\
\hline Years of education & 10.80 & 3.33 & 8.00 & 11.50 & 12.00 & 16.00 \\
\hline Years shop open & 7.47 & 5.60 & 3.16 & 6.41 & 9.90 & 14.56 \\
\hline Male & 0.56 & - & - & - & - & - \\
\hline Married & 0.79 & - & - & - & - & - \\
\hline Age & 33.36 & 9.48 & 27.00 & 32.00 & 38.00 & 46.00 \\
\hline Can read and write (Swahili) & 0.97 & & & & & \\
\hline \multicolumn{7}{|l|}{ Asset ownership and formal-sector income } \\
\hline Owner or spouse has a formal sector job & 0.13 & - & - & - & - & - \\
\hline Acres land owned & 1.95 & 2.64 & 0.00 & 1.00 & 2.50 & 4.50 \\
\hline Value of durable goods and animals owned & 11.70 & 15.32 & 4.20 & 7.00 & 11.91 & 25.50 \\
\hline \multicolumn{7}{|l|}{ Financial access } \\
\hline Has bank account & 0.83 & - & - & - & - & - \\
\hline Participates in ROSCA & 0.42 & - & - & - & - & - \\
\hline $\begin{array}{l}\text { Would you like to borrow more money but } \\
\text { are unable to get it (percentage "yes") }\end{array}$ & 0.37 & - & - & - & - & - \\
\hline \multicolumn{7}{|l|}{ Small-stakes risk aversion } \\
\hline Percentage invested in risky asset & 0.56 & 0.20 & 0.50 & 0.50 & 0.70 & 0.80 \\
\hline \multicolumn{7}{|l|}{ Time preferences } \\
\hline $\begin{array}{l}\text { "Patient:" Prefers } 55 \text { KSh or less in } 1 \text { month } \\
\text { to } 40 \text { KSh today }\end{array}$ & 0.08 & - & - & - & - & $\ldots$ \\
\hline Time consistent & 0.20 & - & - & - & - & - \\
\hline Present biased & 0.52 & - & - & - & - & - \\
\hline Patient now but impatient later & 0.06 & - & - & - & - & - \\
\hline Maximally impatient in present and future & 0.22 & - & - & - & - & - \\
\hline \multicolumn{7}{|l|}{ Attitudinal measures } \\
\hline Work importance index & 0.36 & 0.19 & 0.25 & 0.25 & 0.50 & 0.50 \\
\hline \multicolumn{7}{|l|}{ Financial recordkeeping } \\
\hline Always keeps financial records & 0.31 & - & - & - & - & - \\
\hline
\end{tabular}

Notes: There are 380 shops in the sample. Sample size differs for some variables. All monetary values in 10,000 Kenyan shillings. Exchange rate was roughly $75 \mathrm{KSh}$ to $\$ 1$.

should be close to risk neutral over such small stakes (i.e., Rabin 2000), the lumping at an equal division of assets suggests that investment behavior is not consistent with expected utility maximization.

In terms of time preferences in laboratory games, respondents appear very impatient on average. Only 8 percent of people are willing to wait a month 
for $55 \mathrm{KSh}$ instead of receiving $40 \mathrm{KSh}$ immediately. While this may suggest high discount rates, this measure may be confounded by trust concerns as well. Only 20 percent of people are time consistent, whereas 52 percent are present biased. Of the attitudinal variables, a "work importance" index was constructed by averaging responses to the following four questions: (a) a binary variable equal to 1 if the respondent answers "all the time" to the question "How often do you think about your business?"; (b) a binary variable taking value 1 if the shopkeeper reports that she tends to choose work over family; (c) a binary variable taking value 1 for shopkeepers who say that work is "very important"; and (d) a binary variable taking value 1 for those who say their goal in the business is to "make a lot of money." The average of this index is 0.36 in the sample. Finally, the last row of the table shows that only 31 percent of shops always keep financial records.

\section{Mathematical Ability}

Figure 9.1 shows the distribution of scores on the eleven-question mathematical test. ${ }^{7}$ There is quite a bit of variation in scores. The interquartile range is $0.36-0.6$, while the mean and median are 0.49 and 0.45 , respectively. Table 9.2 shows how scores on the math test are correlated with other measures, and examines the relationship between mathematical ability, education, and other cognitive measures (note that this table includes data from all shopkeepers who completed the math test in the baseline sample, whether or not they were in the end line). In column (1), the standardized math score is regressed on years of education. The correlation is positive, large, and highly significant; an additional year of education is associated with an additional 0.13 standard deviation score on the math test. Column (2) includes other controls, including standardized measures of digit recall, maze completion times, Raven's matrix score, and a combined English/Kiswahili language score. These covariates somewhat attenuate the effect of education (from 0.13 to 0.07 standard deviations per year of education), but the coefficient is still highly significant. The results do not suggest statistically significant correlations between the math score and either the Raven's score or the language score.

As will be discussed in greater detail in the following sections, these correlations are important for two reasons. First, they provide some reassurance that these measures contain some signal. Second, the correlation with education at least suggests that mathematical ability is not an innate individual characteristic, but is something that could potentially be improved with training.

7. Note that some subjects did not answer all questions, and some questions were filled in incorrectly or were subject to data entry errors. Therefore, data is not available for answers to all questions for all respondents. 


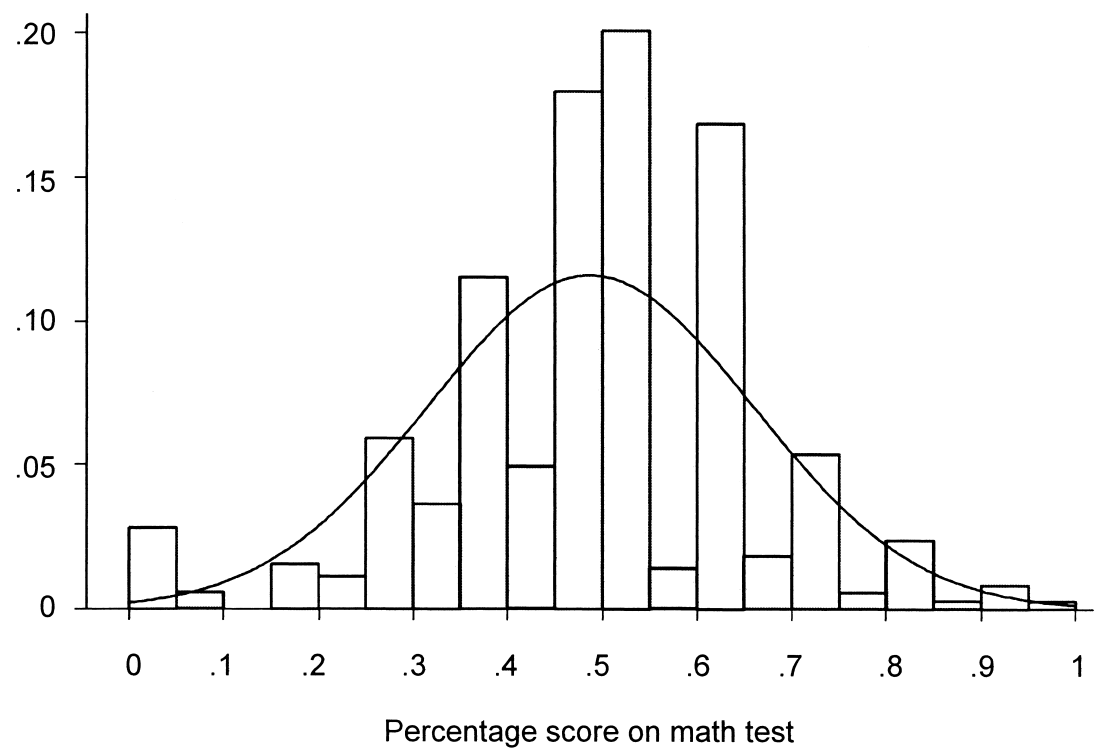

Fig. 9.1 Distribution of scores on math test

Table 9.2 Correlates of standardized math score

(1)

(2)

Years of education

0.13

0.07

$(0.01)^{* * *} \quad(0.01)^{* * *}$

Digit recall (standardized)

Seconds to finish mazes (standardized)

Raven's matrix (standardized)

0.26

$(0.04)^{* * *}$

Combined language score (standardized)

0.09

$(0.04)^{* *}$

Observations

670

620

$R$-squared

0.19

0.22

Notes: The dependent variable is the score on the math exam. Regressions include all firms with either inventory/profit data, or survival data. To avoid dropping observations, we create dummy variables for having missing information for a given variable and code the underlying variable as a 0 when it is missing.

$* * *$ Significant at the 1 percent level.

**Significant at the 5 percent level.

*Significant at the 10 percent level. 


\subsection{Results}

\subsubsection{Inventory Size}

First, the multivariate correlates of inventory size are considered, using the two measures of $(\log )$ inventories, both in Kenyan shillings. These results are presented in table 9.3. In columns (1)-(3), the dependent variable is log total inventory on all items; in columns (4)-(6), it is log inventory on the top thirteen items. In the first specification (columns [1] and [4]), only those variables that are most plausibly exogenous are included. In addition to demographic characteristics, these include measures of cognitive ability, small-stakes risk aversion, asset ownership, and income from formalsector jobs. In the second specification (columns [2] and [5]), measures of financial access are added. In the final specification (columns [3] and [6]), time preferences, attitudinal measures, and financial record keeping are also included.

The most compelling associations emerge with respect to the cognitive measures. There is strong evidence that shopkeepers' performance on the math test predicts inventory size. As with small-stakes risk aversion, this association is robust to controlling for measures of credit constraints and other variables. A one standard deviation increase in the math score is robustly associated with $16-18$ percent higher inventories. Raven's matrix scores are also significant in predicting the inventory of the top thirteen products (columns [4]-[6]), but are not significant with regard to total inventory.

The only demographic variable correlated with inventories is the shopkeeper's age; firms with younger owners tend to have larger inventories. There is some evidence that some measures of credit constraints may be important, though the overall pattern of results does not provide definitive evidence one way or the other. Higher levels of other assets are weakly correlated larger inventories. However, there is no significant correlation between inventories and self-reported credit constraints, land ownership, or formal-sector employment. There is some evidence that those with bank accounts have larger inventories, while members of savings circles called ROSCAs (Rotating Savings and Credit Associations) have smaller inventories (Kremer et al. 2013a). While it is difficult to interpret this causally, one possible explanation is that most shopkeepers have bank accounts (as can be seen from table 9.1, 82 percent have bank accounts) and thus shopkeepers who save in ROSCAs may be worse off than the average shopkeeper.

There is strong evidence that small-stakes loss aversion is significantly correlated with lower inventories. This correlation is robust to controlling for measures of credit constraints, as well as for other variables. Shopkeepers who invested 10 percent less of the $100 \mathrm{KSh}$ portfolio (i.e., $10 \mathrm{KSh}$ ) in the risky asset had approximately 6.6-8.1 percent higher inventories. While it 
Log inventory on top

Log total inventory 13 products
(1)
(2)
(3)
(4)
(5)
(6)

Background characteristics

Years of education (tens of years)

Years shop open (tens of years)

$\begin{array}{cccccc}-0.06 & -0.09 & -0.14 & 0.04 & -0.01 & -0.06 \\ (0.20) & (0.20) & (0.20) & (0.21) & (0.21) & (0.21) \\ 0.16 & 0.12 & 0.16 & 0.20 & 0.17 & 0.20 \\ (0.10) & (0.10) & (0.10) & (0.11)^{*} & (0.11) & (0.11)^{*} \\ -0.01 & -0.02 & -0.01 & -0.02 & -0.02 & -0.02 \\ (0.01)^{* *} & (0.01)^{* * *} & (0.01)^{* *} & (0.01)^{* * *} & (0.01)^{* * *} & (0.01)^{* * *}\end{array}$

Cognitive measures

Math score (standardized)

Raven's matrix (standardized)

$\begin{array}{cccccc}0.18 & 0.18 & 0.16 & 0.14 & 0.14 & 0.12 \\ (0.06)^{* * *} & (0.06)^{* * *} & (0.06)^{* * *} & (0.06)^{* *} & (0.06)^{* *} & (0.06)^{*} \\ 0.07 & 0.05 & 0.06 & 0.15 & 0.13 & 0.14 \\ (0.07) & (0.06) & (0.06) & (0.07)^{* *} & (0.07)^{* *} & (0.07)^{* *} \\ -0.02 & -0.03 & -0.03 & -0.04 & -0.05 & -0.06 \\ (0.07) & (0.07) & (0.07) & (0.07) & (0.07) & (0.07) \\ 0.03 & 0.03 & 0.03 & 0.03 & 0.03 & 0.03 \\ (0.07) & (0.07) & (0.07) & (0.07) & (0.07) & (0.07) \\ 0.02 & 0.04 & 0.05 & 0.01 & 0.03 & 0.04 \\ (0.07) & (0.07) & (0.07) & (0.07) & (0.07) & (0.07)\end{array}$

Small-stakes risk aversion

Percentage invested in risky asset

$\begin{array}{llllll}0.79 & 0.81 & 0.66 & 0.51 & 0.54 & 0.39\end{array}$ (out of $100 \mathrm{KSh}$ )

$(0.23)^{* * *} \quad(0.23)^{* * *} \quad(0.24)^{* *}$

$(0.24)^{* *} \quad(0.24)^{* *}$

(0.25)

Asset ownership and formal-sector income

Owner or spouse has a formal-sector job

Log (acres land owned + 1)

$\begin{array}{cccccc}-0.04 & 0.00 & -0.03 & -0.15 & -0.12 & -0.14 \\ (0.18) & (0.17) & (0.17) & (0.18) & (0.18) & (0.18) \\ 0.03 & 0.07 & 0.08 & 0.02 & 0.05 & 0.06 \\ (0.08) & (0.08) & (0.08) & (0.09) & (0.09) & (0.09) \\ 0.25 & 0.22 & 0.22 & 0.21 & 0.17 & 0.17 \\ (0.13)^{*} & (0.13)^{*} & (0.13)^{*} & (0.13)^{*} & (0.13) & (0.13)\end{array}$

Log (value of durable goods and animals owned +1 ) (in 10,000 KSh)

Financial access

Has bank account

$\begin{array}{ll}0.19 & 0.20 \\ (0.13) & (0.13) \\ -0.48 & -0.48 \\ (0.12)^{* * *} & (0.12)^{* * *} \\ 0.00 & 0.01 \\ (0.11) & (0.11)\end{array}$

0.27

0.29

Participates in ROSCA

Would like to borrow more money but is unable to get it

(0.11)

$(0.11)$

$(0.14)^{* *} \quad(0.14)^{* *}$

$-0.50$

$-0.49$

$(0.12)^{* * *}(0.12)^{* * *}$

$-0.02 \quad-0.01$

(0.12) (0.12)

Time preferences, attitudinal measures, and financial record keeping

"Patient:" Prefers 55 KSh or less in 1

$-0.05$

0.20

month to $40 \mathrm{KSh}$ today

$(0.27)$

(0.28)

Time consistent

$-0.04$

$-0.12$

(0.14)

(0.14)

$-0.40$

$-0.26$

$(0.17)^{* *}$

(0.18)

$-0.31$

$-0.17$

(0.30)

(0.31)

(continued) 
Table 9.3 (continued)

\begin{tabular}{|c|c|c|c|c|c|c|}
\hline & \multicolumn{3}{|c|}{ Log total inventory } & \multicolumn{3}{|c|}{$\begin{array}{l}\text { Log inventory on top } \\
13 \text { products }\end{array}$} \\
\hline & (1) & (2) & (3) & (4) & (5) & (6) \\
\hline Work importance index & & & $\begin{array}{l}0.64 \\
(0.27)^{* *}\end{array}$ & & & $\begin{array}{l}0.56 \\
(0.28)^{* *}\end{array}$ \\
\hline Always keeps financial records & & & $\begin{array}{l}0.25 \\
(0.12)^{* *}\end{array}$ & & & $\begin{array}{l}0.27 \\
(0.12)^{* *}\end{array}$ \\
\hline Mean of dependent variable & 11.97 & 11.97 & 11.97 & 10.89 & 10.89 & 10.89 \\
\hline Std. dev. of dependent variable & 1.06 & 1.06 & 1.06 & 1.09 & 1.09 & 1.09 \\
\hline Observations & 380 & 380 & 380 & 380 & 380 & 380 \\
\hline$R$-squared & 0.10 & 0.14 & 0.18 & 0.09 & 0.14 & 0.17 \\
\hline
\end{tabular}

Notes: Dependent variables in (log) Kenyan shillings. To avoid dropping observations, we create dummy variables for having missing information for a given variable and code the underlying variable as a 0 when it is missing. Regressions also include for gender, marital status, and literacy. Standard errors in parentheses.

$* * *$ Significant at the 1 percent level.

**Significant at the 5 percent level.

*Significant at the 10 percent level.

is possible that the decision of how much to allocate to a risky portfolio is endogenous to business performance such that less successful shopkeepers invest less in the asset, this seems unlikely given the small stakes: $10 \mathrm{KSh}$ represents only around 1/700th of the value of the median shopkeeper's durable goods and animal assets, and only around 1/1400th of the value of the median respondent's inventory.

There is also evidence that some measures of time preferences are associated with inventories. Though these are less clearly exogenous to inventory size, the patterns are intuitive - present-biased owners hold smaller inventories. However, the measure of "patience" in the present is not correlated with inventories.

The work importance index and financial record keeping are correlated with inventories in ways that seem sensible. Owners who place more importance on work at the expense of other activities hold bigger inventories, as do owners who always keep financial records.

\subsubsection{Profits}

Next, the correlates of shops' reported profits over the last thirty days of operation are examined (table 9.4). The first three specifications in this table are identical to those in table 9.3. Since inventories and profits are positively correlated, two more specifications are added. Column (4) includes a control for log total inventory size, while column (5) includes log inventory of the top thirteen items. This was done to examine whether the relationships between profits and owner and shop characteristics work entirely through inventories 
Log profits in past 30 days

(1) (2) (3) (4)

(5)

\begin{tabular}{|c|c|c|c|c|c|}
\hline \multicolumn{6}{|l|}{ Background characteristics } \\
\hline Years of education (tens of years) & $\begin{array}{c}0.17 \\
(0.27)\end{array}$ & $\begin{array}{c}0.12 \\
(0.28)\end{array}$ & $\begin{array}{c}0.08 \\
(0.27)\end{array}$ & $\begin{array}{c}0.27 \\
(0.21)\end{array}$ & $\begin{array}{c}0.20 \\
(0.22)\end{array}$ \\
\hline Years shop open (tens of years) & $\begin{array}{c}0.06 \\
(0.14)\end{array}$ & $\begin{array}{c}0.08 \\
(0.14)\end{array}$ & $\begin{array}{c}0.09 \\
(0.14)\end{array}$ & $\begin{array}{c}-0.02 \\
(0.11)\end{array}$ & $\begin{array}{c}-0.05 \\
(0.12)\end{array}$ \\
\hline Age & $\begin{array}{l}-0.02 \\
(0.01)^{* *}\end{array}$ & $\begin{array}{l}-0.02 \\
(0.01)^{*}\end{array}$ & $\begin{array}{c}-0.01 \\
(0.01)\end{array}$ & $\begin{array}{c}-0.01 \\
(0.01)\end{array}$ & $\begin{array}{c}-0.01 \\
(0.01)\end{array}$ \\
\hline \multicolumn{6}{|l|}{ Cognitive measures } \\
\hline Math score (standardized) & $\begin{array}{l}0.32 \\
(0.09)^{* * *}\end{array}$ & $\begin{array}{l}0.32 \\
(0.09)^{* * *}\end{array}$ & $\begin{array}{l}0.32 \\
(0.09)^{* * *}\end{array}$ & $\begin{array}{l}0.16 \\
(0.07)^{* *}\end{array}$ & $\begin{array}{l}0.23 \\
(0.07)^{* * *}\end{array}$ \\
\hline Raven's matrix (standardized) & $\begin{array}{c}-0.13 \\
(0.09)\end{array}$ & $\begin{array}{c}-0.13 \\
(0.09)\end{array}$ & $\begin{array}{c}-0.06 \\
(0.09)\end{array}$ & $\begin{array}{c}-0.03 \\
(0.07)\end{array}$ & $\begin{array}{c}-0.11 \\
(0.07)\end{array}$ \\
\hline Digit recall (standardized) & $\begin{array}{c}0.13 \\
(0.09)\end{array}$ & $\begin{array}{c}0.11 \\
(0.09)\end{array}$ & $\begin{array}{c}0.12 \\
(0.09)\end{array}$ & $\begin{array}{c}0.00 \\
(0.07)\end{array}$ & $\begin{array}{c}-0.01 \\
(0.08)\end{array}$ \\
\hline Seconds to finish mazes (standardized) & $\begin{array}{c}0.15 \\
(0.09)\end{array}$ & $\begin{array}{c}0.15 \\
(0.09)\end{array}$ & $\begin{array}{c}0.15 \\
(0.09)^{*}\end{array}$ & $\begin{array}{c}0.10 \\
(0.07)\end{array}$ & $\begin{array}{c}0.07 \\
(0.07)\end{array}$ \\
\hline Combined language score (standardized) & $\begin{array}{c}0.08 \\
(0.09)\end{array}$ & $\begin{array}{c}0.11 \\
(0.09)\end{array}$ & $\begin{array}{c}0.07 \\
(0.09)\end{array}$ & $\begin{array}{c}0.03 \\
(0.07)\end{array}$ & $\begin{array}{c}0.05 \\
(0.07)\end{array}$ \\
\hline \multicolumn{6}{|l|}{ Small-stakes risk aversion } \\
\hline $\begin{array}{l}\text { Percentage invested in risky asset (out of } \\
100 \mathrm{KSh} \text { ) }\end{array}$ & $\begin{array}{l}0.79 \\
(0.32)^{* *}\end{array}$ & $\begin{array}{l}0.80 \\
(0.32)^{* *}\end{array}$ & $\begin{array}{l}0.70 \\
(0.32)^{* *}\end{array}$ & $\begin{array}{c}0.17 \\
(0.25)\end{array}$ & $\begin{array}{c}0.23 \\
(0.26)\end{array}$ \\
\hline \multicolumn{6}{|l|}{ Asset ownership and formal-sector income } \\
\hline Owner or spouse has a formal-sector job & $\begin{array}{c}0.17 \\
(0.24)\end{array}$ & $\begin{array}{c}0.18 \\
(0.24)\end{array}$ & $\begin{array}{c}0.03 \\
(0.24)\end{array}$ & $\begin{array}{c}0.13 \\
(0.19)\end{array}$ & $\begin{array}{c}0.22 \\
(0.20)\end{array}$ \\
\hline Log (acres land owned +1$)$ & $\begin{array}{c}0.07 \\
(0.11)\end{array}$ & $\begin{array}{l}0.10 \\
(0.11)\end{array}$ & $\begin{array}{c}0.11 \\
(0.11)\end{array}$ & $\begin{array}{c}0.08 \\
(0.08)\end{array}$ & $\begin{array}{c}0.06 \\
(0.09)\end{array}$ \\
\hline $\begin{array}{l}\text { Log (value of durable goods and animals } \\
\text { owned }+1)(\text { in } 10,000 \mathrm{KSh})\end{array}$ & $\begin{array}{c}0.16 \\
(0.16)\end{array}$ & $\begin{array}{c}0.11 \\
(0.17)\end{array}$ & $\begin{array}{c}0.10 \\
(0.17)\end{array}$ & $\begin{array}{c}0.01 \\
(0.13)\end{array}$ & $\begin{array}{c}0.06 \\
(0.13)\end{array}$ \\
\hline \multicolumn{6}{|l|}{ Financial access } \\
\hline Has bank account & & $\begin{array}{c}0.25 \\
(0.18)\end{array}$ & $\begin{array}{c}0.23 \\
(0.17)\end{array}$ & $\begin{array}{c}-0.02 \\
(0.14)\end{array}$ & $\begin{array}{c}-0.09 \\
(0.14)\end{array}$ \\
\hline Participates in ROSCA & & $\begin{array}{l}-0.20 \\
(0.16)\end{array}$ & $\begin{array}{l}-0.19 \\
(0.15)\end{array}$ & $\begin{array}{c}0.08 \\
(0.12)\end{array}$ & $\begin{array}{c}0.01 \\
(0.13)\end{array}$ \\
\hline $\begin{array}{l}\text { Would like to borrow more money but is } \\
\text { unable to get it }\end{array}$ & & $\begin{array}{l}-0.13 \\
(0.15)\end{array}$ & $\begin{array}{l}-0.15 \\
(0.14)\end{array}$ & $\begin{array}{l}-0.13 \\
(0.11)\end{array}$ & $\begin{array}{c}-0.09 \\
(0.12)\end{array}$ \\
\hline \multicolumn{6}{|l|}{$\begin{array}{l}\text { Time preferences, attitudinal measures, and } \\
\text { financial record keeping }\end{array}$} \\
\hline $\begin{array}{l}\text { "Patient:" Prefers } 55 \mathrm{KSh} \text { or less in } 1 \text { month } \\
\text { to } 40 \mathrm{KSh} \text { today }\end{array}$ & & & $\begin{array}{l}-0.81 \\
(0.37)^{* *}\end{array}$ & $\begin{array}{l}-0.33 \\
(0.29)\end{array}$ & $\begin{array}{l}-0.54 \\
(0.30)^{*}\end{array}$ \\
\hline Time consistent & & & $\begin{array}{c}0.08 \\
(0.19)\end{array}$ & $\begin{array}{l}-0.13 \\
(0.15)\end{array}$ & $\begin{array}{l}-0.06 \\
(0.16)\end{array}$ \\
\hline Present biased & & & $\begin{array}{l}-0.11 \\
(0.20)\end{array}$ & $\begin{array}{c}0.15 \\
(0.16)\end{array}$ & $\begin{array}{c}0.08 \\
(0.16)\end{array}$ \\
\hline Patient now, impatient later & & & $\begin{array}{l}-0.84 \\
(0.45)^{*}\end{array}$ & $\begin{array}{c}-0.31 \\
(0.34)\end{array}$ & $\begin{array}{c}-0.42 \\
(0.36)\end{array}$ \\
\hline Work importance index & & & $\begin{array}{c}0.74 \\
(0.38)^{*}\end{array}$ & $\begin{array}{c}0.40 \\
(0.29)\end{array}$ & $\begin{array}{c}0.55 \\
(0.31)^{*} \\
\text { (continued) }\end{array}$ \\
\hline
\end{tabular}


Table 9.4 (continued)

\begin{tabular}{lccccc}
\hline & \multicolumn{5}{c}{ Log profits in past 30 days } \\
\cline { 2 - 6 } & $(1)$ & $(2)$ & $(3)$ & $(4)$ & $(5)$ \\
\hline Always keeps financial records & & & 0.36 & 0.16 & 0.16 \\
& & & $(0.16)^{* *}$ & $(0.13)$ & $(0.14)$ \\
Inventory & & & & 0.58 \\
$\quad$ Log total inventory & & & & $(0.06)^{* * *}$ & \\
& & & & & 0.52 \\
$\quad$ Log inventory on top 13 items & 9.62 & 9.62 & 9.62 & 9.61 & 9.61 \\
Mean of dependent variable & 1.00 & 1.00 & 1.00 & 0.97 & 0.97 \\
Std. dev. of dependent variable & 188 & 188 & 188 & 184 & 184 \\
Observations & 0.17 & 0.19 & 0.27 & 0.56 & 0.51 \\
$R$-squared & & & & & \\
\hline
\end{tabular}

Notes: Dependent variables in (log) Kenyan shillings. To avoid dropping observations, we create dummy variables for having missing information for a given variable and code the underlying variable as a 0 when it is missing. Regressions also include for gender, marital status, and literacy. Standard errors in parentheses.

***Significant at the 1 percent level.

**Significant at the 5 percent level.

*Significant at the 10 percent level.

(such that certain types of shopkeepers run larger shops), or whether certain types of people are better able to manage a given amount of inventory.

The only covariate that is robustly significant both with and without an inventory control is the math score. Unconditional on inventories, a one standard deviation increase in the math score is associated with 32 percent higher profits; conditional on inventories, the figure falls by about half, suggesting that one of the main channels through which quantitative ability factors into profits is inventory management (columns [4]-[5], table 9.5). However, even conditional on inventories, quantitative ability appears to be an important predictor of profits.

Though there are fewer other correlates that are statistically significant, the pattern is generally similar. There are several correlates that are statistically significant when inventories are not included as a control: younger shop owners, shop owners who keep financial records, and shop owners who place higher importance on work all tend to earn higher profits. One somewhat surprising result is that shop owners who are rated as "patient" earn less (i.e., those that prefer $55 \mathrm{KSh}$ or less in 1 month to $40 \mathrm{KSh}$ now). Perhaps these shops have higher returns to inventory. In any case, none of these covariates remain significant when inventories are included (columns [4]-[5]), suggesting that they work principally through an inventory channel.

Again, small-stakes risk aversion is positively correlated with profits. The data suggests that this association works mostly through the inventory channel (see columns [4]-[5]): the coefficient is attenuated to about one-quarter 
Shop still open in May 2011

Age

Cognitive measures

Math score (standardized)

Raven's matrix (standardized)

Digit recall (standardized)

Seconds to finish mazes (standardized)

Combined language score (standardized)

Small-stakes risk aversion

Percentage invested in risky asset (out of $100 \mathrm{KSh}$ )

Asset ownership and formal-sector income

Owner or spouse has a formal sector job

$\log ($ acres land owned +1$)$

Log (value of durable goods and animals owned +1 ) (in $10,000 \mathrm{KSh})$

Financial access

Has bank account

Participates in ROSCA

Would like to borrow more money but is unable to get it

Time preferences, attitudinal measures, and financial record keeping

"Patient:" Prefers 55 KSh or less in 1 month to 40 KSh today

Time consistent

Present biased

Patient now, impatient later

Work importance index

(1)
(2)

(3)

\begin{tabular}{|c|c|c|}
\hline 0.02 & 0.03 & 0.02 \\
\hline$(0.04)$ & $(0.04)$ & $(0.04)$ \\
\hline 0.04 & 0.03 & 0.04 \\
\hline$(0.02)^{*}$ & $(0.02)^{*}$ & $(0.02)^{*}$ \\
\hline 0.00 & 0.00 & 0.00 \\
\hline$(0.01)$ & $(0.01)$ & $(0.01)$ \\
\hline 0.00 & 0.00 & 0.00 \\
\hline$(0.01)$ & $(0.01)$ & $(0.01)$ \\
\hline 0.02 & 0.02 & 0.03 \\
\hline$(0.01)^{*}$ & $(0.01)^{*}$ & $(0.01)^{*}$ \\
\hline 0.00 & 0.00 & 0.00 \\
\hline$(0.01)$ & $(0.01)$ & $(0.01)$ \\
\hline 0.02 & 0.02 & 0.02 \\
\hline$(0.01)$ & $(0.01)$ & $(0.01)$ \\
\hline-0.01 & -0.01 & -0.02 \\
\hline$(0.01)$ & $(0.01)$ & $(0.01)$ \\
\hline $\begin{array}{l}-0.13 \\
(0.5) * * *\end{array}$ & -0.13 & -0.16 \\
\hline & & \\
\hline-0.03 & -0.03 & -0.02 \\
\hline$(0.03)$ & $(0.03)$ & $(0.03)$ \\
\hline-0.01 & -0.01 & -0.01 \\
\hline$(0.02)$ & $(0.02)$ & $(0.02)$ \\
\hline 0.02 & 0.02 & 0.01 \\
\hline \multirow[t]{7}{*}{$(0.03)$} & $(0.03)$ & $(0.03)$ \\
\hline & -0.01 & -0.01 \\
\hline & $(0.03)$ & $(0.03)$ \\
\hline & -0.01 & -0.01 \\
\hline & $(0.02)$ & $(0.02)$ \\
\hline & -0.02 & -0.02 \\
\hline & $(0.02)$ & $(0.02)$ \\
\hline
\end{tabular}

$-0.04$

$(0.06)$

0.00

$(0.03)$

0.06

$(0.04)$

$-0.01$

(0.07)

0.07

(0.06)

(continued) 
Table 9.5 (continued)

Shop still open in May 2011

(1)

(2)

Always keeps financial records

Mean of dependent variable

Std. dev. of dependent variable

Observations

0.28

0.91

700

0.28

$R$-squared

0.04

0.28

700

Notes: To avoid dropping observations, we create dummy variables for having missing information for a given variable and code the underlying variable as a 0 when it is missing. Regressions also include for gender, marital status, and literacy. Standard errors in parentheses.

$* * *$ Significant at the 1 percent level.

**Significant at the 5 percent level.

*Significant at the 10 percent level.

of its size, and is no longer significant when inventories are included as a control.

\subsubsection{Firm Survival}

Table 9.5 examines multivariate regressions correlates of firm survival. Overall, 91 percent of businesses were still open in May 2011, implying an annual exit rate of approximately 4-6 percent. Few background characteristics predict survival. Unsurprisingly, the longer a shop has been open the more likely it is to survive. The Raven's matrix cognitive measure positively correlates with survival, while the math score is not predictive at all. None of the proxies for credit constraints are correlated with survival.

The only strongly predictive characteristic is small-stakes risk aversion, suggesting that shop owners who are less risk averse over small stakes are actually less likely to remain in business. This last result suggests that survival may not be a positive outcome for shopkeepers (unfortunately, data on reasons for exit could not be obtained). In particular, exiting small retail into salaried work would typically make people better off. That there are not many robust predictors of survival would be consistent with this view, as would the correlation between scores on Raven's matrix pattern recognition task and likelihood of survival. Potentially, this suggests that successful retail shops exit into other, more profitable businesses.

\subsection{Conclusion}

This chapter examines correlates of various measures of entrepreneurial success with shop and owner characteristics among small retailers in western 
Kenya. The finding that stands out most strongly is a very high correlation of math scores with our measures of success. Math scores seem to be a robust predictor of inventories. They also strongly predict profits, and while one channel seems to be inventories, math scores appear to important beyond this: the regression of profits on math scores controlling for inventories still shows a significant positive coefficient. Unsurprisingly, math scores are highly correlated with education. One hypothesis worth examining is that programs to improve math skills may be able increase the success of entrepreneurs.

Interestingly, other cognitive measures such as language scores, Raven matrix tests, digit recall, and time to complete mazes are not as robustly correlated with entrepreneurial success. There is some evidence that there is a relationship between inventory size and some measures of credit constraints. Other factors seem to be somewhat important as well. Present-biased shopkeepers have smaller shops. Shopkeepers who regularly keep financial records and shopkeepers who report placing a higher value on work over other aspects of their lives have larger shops. However, our analysis does not find correlations of inventories or profits with most shopowner characteristics (i.e., years of education, formal sector income, land ownership, and selfreported credit constraints).

A very strong relationship between inventories and small-stakes risk aversion was also observed. As risk aversion over such small stakes is implausible for expected utility maximizers (e.g., Rabin 2000), our companion paper (Kremer et al. 2013a) postulates that the correlation between small-stakes risk aversion and inventory size is due to loss aversion. As discussed in that paper, loss aversion may be an explanation for why millions of firms are unable to exploit potential profit opportunities. 


\section{Appendix}

Table 9A.1

Math questionnaire

F_1 Look at the row of numbers below. What number should come next? $84211 / 21 / 4$ ?

F_2 A notebook costs $21 \mathrm{KSh}$ for each one. What will four notebooks cost?

$\mathrm{KSh}$

F_3 How many of the five pairs of items listed below are exactly the same? Circle the same ones.

$\begin{array}{lll}1 & \text { Nieman, K. M. } & \text { Neiman, K. M. } \\ 2 & \text { Thomas, G. K. } & \text { Thomas, C. K. } \\ 3 & \text { Hoff, J. P. } & \text { Hoff, J. P. } \\ 4 & \text { Pino, L. R. } & \text { Pina, L. R. } \\ 5 & \text { Warner, T. S. } & \text { Wanner, T. S. }\end{array}$

F_4 Which one of the numbered figures below is most different from the others? Circle the number.

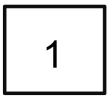

1

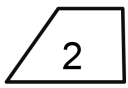

2

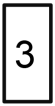

3

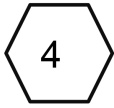

4

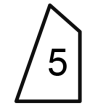

5

F_5 A bus travels 20 meters in 1/5 second (one-fifth of a second). At the same speed, how far will it travel in three seconds?

meters

F_6 Rope costs $10 \mathrm{KSh}$ a meter. How many meters can you buy for $60 \mathrm{KSh}$ ?

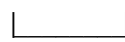

meters

F_7 Which number in the following group of numbers represents the smallest amount? Circle the smallest.
(a) 7
(b) $2 / 5$
(c) 31
(d) $1 / 3$
(e) 2

F_8 A boy is seventeen years old and his sister is twice as old. When the boy is twenty-three years old, what will be the age of his sister?

F_9 Trousers and a shirt cost 1,100 KSh in total. The trousers cost 1,000 KSh more than the shirt. How much does the shirt cost?

F_10 If it takes five machines five minutes to make five cars, how long would it take 100 machines to make 100 cars?

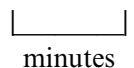

F_11 In a lake, there is a patch of water hyacinths. Every day, the patch doubles in size (becomes twice as big). If it takes forty-eight days for the patch to cover the entire lake, how long would it take for the patch to cover half of the lake? 
Quantiles

Mean Std. dev. 25th 50th 75th 90th

(1)

(2)

(3)

(4)

(5)

(6)

Inventories, profits, and credit to customers

Total survival

Survival in top 13 items

Profits in past month

Gives out credit to customers

Amount given out in credit in past month

Background characteristics

Years of education

Years shop open

Male

Married

Age

Can read and write (Swahili)

Asset ownership and formal-sector income

Owner or spouse has a formal sector job

Acres land owned

Value of durable goods and animals owned

Financial access

Has bank account

Participates in ROSCA

Would you like to borrow more money but are unable to get it (percentage "yes")

Small-stakes risk aversion

Percentage invested in risky asset

Time preferences

"Patient:" Prefers 55 KSh or less in 1 month to $40 \mathrm{KSh}$ today

Time consistent

Present biased

Patient now but impatient later

Maximally impatient in present and future

Attitudinal measures

Work importance index

Financial record keeping

Always keeps financial records

\begin{tabular}{|c|c|c|c|c|c|}
\hline 26.64 & 29.75 & 8.00 & 15.00 & 30.00 & 70.00 \\
\hline 9.47 & 11.38 & 2.83 & 5.17 & 10.82 & 25.01 \\
\hline 2.47 & 2.87 & 0.80 & 1.20 & 3.43 & 6.00 \\
\hline 0.91 & - & - & - & - & - \\
\hline 1.11 & 5.72 & 0.10 & 0.20 & 0.45 & 1.50 \\
\hline 10.51 & 3.35 & 8.00 & 11.00 & 12.00 & 16.00 \\
\hline 6.56 & 5.89 & 2.16 & 4.88 & 9.30 & 14.24 \\
\hline 0.52 & - & - & - & - & - \\
\hline 0.80 & - & - & - & - & - \\
\hline 33.42 & 9.57 & 27.00 & 32.00 & 38.00 & 46.00 \\
\hline 0.97 & & & & & \\
\hline 0.15 & - & - & - & - & - \\
\hline 1.97 & 2.92 & 0.00 & 1.00 & 2.50 & 4.00 \\
\hline 10.83 & 14.29 & 3.97 & 6.56 & 11.35 & 19.88 \\
\hline 0.82 & - & - & - & - & - \\
\hline 0.43 & - & - & - & - & - \\
\hline 0.37 & - & - & - & - & - \\
\hline 0.57 & 0.20 & 0.50 & 0.50 & 0.70 & 0.80 \\
\hline 0.08 & - & - & - & - & - \\
\hline 0.18 & - & - & - & - & - \\
\hline 0.51 & - & - & - & - & - \\
\hline 0.05 & - & - & - & - & - \\
\hline 0.25 & - & - & - & - & - \\
\hline 0.35 & 0.19 & 0.25 & 0.25 & 0.50 & 0.50 \\
\hline 0.28 & - & - & - & - & - \\
\hline
\end{tabular}

Notes: There are 687 shops in the sample. Sample size differs for some variables. All monetary values in 10,000 Kenyan shillings. Exchange rate was roughly $75 \mathrm{KSh}$ to $\$ 1$. 


\section{References}

Banerjee, A., and E. Duflo. 2007. "The Economic Lives of the Poor." Journal of Economic Perspectives 21 (1): 141-67.

2012. "Do Firms Want to Borrow More? Testing Credit Constraints Using a Directed Lending Program." Unpublished Manuscript, MIT.

Banerjee, A., D. Karlan, and J. Zinman. 2015. "Six Randomized Evaluations of Microcredit: Introduction and Further Steps." American Economic Journal: Applied Economics 7 (1): 1-21.

Benartzi, S., and R. H. Thaler. 2001. "Naïve Diversification Strategies in Defined Contribution Saving Plans." American Economic Review 91 (1): 79-98.

- 2007. "Heuristics and Biases in Retirement Savings Behavior." Journal of Economic Perspectives 21 (3): 81-104.

Blanchflower, D., and A. Oswald. 1998. "What Makes an Entrepreneur?” Journal of Labor Economics 16 (1): 26-60.

Bloom, N., B. Eifert, A. Mahajan, and D. McKenzie. 2013. "Does Management Matter? Evidence from India." Quarterly Journal of Economics 128 (1): 1-51.

Bruhn, M., D. Karlan, and A. Schoar. 2012. "The Impact of Consulting Services on Small and Medium Enterprises: Evidence from a Randomized Trial in Mexico." Yale Economics Department Working Paper no. 100, Yale University.

Bruhn, M., and B. Zia. 2011. "Stimulating Managerial Capital in Emerging Markets: The Impact of Business and Financial Literacy for Young Entrepreneurs." World Bank Policy Research Working Paper no. 5642, World Bank.

Caliendo, M., F. Fossen, and A. Kritikos. 2010. "The Impact of Risk Attitudes on Entrepreneurial Survival.” Journal of Economic Behavior and Organization 76 (1): 45-63.

Daniels, L., and D. Mead. 1998. "The Contribution of Small Enterprises to Household and National Income in Kenya." Economic Development and Cultural Change 47 (1): 45.

de Mel, S., D. McKenzie, and C. Woodruff. 2008. "Returns to Capital in Microenterprises: Evidence from a Field Experiment." Quarterly Journal of Economics 123 (4): 1329-72.

. 2009a. "Innovative Firms or Innovative Owners? Determinants of Innovation in Micro, Small, and Medium Enterprises.” World Bank Policy Research Paper no. 4934, World Bank.

. 2009b. "Measuring Microenterprise Profits: Must We Ask How the Sausage is Made?" Journal of Development Economics 88 (1): 19-31.

- 2010. "Who are the Microenterprise Owners? Evidence from Sri Lanka on Tokman v. de Soto." In International Differences in Entrepreneurship, edited by J. Lerner and A. Schoar, 63-87. Chicago: University of Chicago Press.

Drexler, A., G. Fischer, and A. Schoar. 2014. "Keeping it Simple: Financial Literacy Training and Rule of Thumbs: Evidence from a Field Experiment." American Economic Journal: Applied Economics 6 (2): 1-31.

Duflo, E., M. Kremer, and J. Robinson. 2011. "Nudging Farmers to Use Fertilizer: Theory and Experimental Evidence from Kenya." American Economic Review 101 (6): 2350-90.

Evans, D., and L. Leighton. 1989. "Some Empirical Aspects of Entrepreneurship." American Economic Review 79:519-35.

Fafchamps, M., D. McKenzie, S. Quinn, and C. Woodruff. 2014. "Microenterprise Growth and the Flypaper Effect: Evidence from a Randomized Experiment in Ghana." Journal of Development Economics 106:211-26. 
Fairlie, R., and W. Holleran. 2012. "Entrepreneurship Training, Risk Aversion and Other Personality Traits: Evidence from a Random Experiment." Journal of Economic Psychology 33 (2): 366-78.

Fairlie, R., D. Karlan, and J. Zinman. 2015. "The Effects of Entrepreneurship Training: Evidence from a Randomized Control Experiment." American Economic Journal: Economic Policy 7 (2): 125-161.

Giné, X., and G. Mansuri. 2011. "Money or Ideas? A Field Experiment on Constraints to Entrepreneurship in Rural Pakistan.” Working Paper, World Bank. http://siteresources.worldbank.org/DEC/Resources/Money_or_Ideas.pdf.

Hartog, J., M. van Praag, and J. van der Sluis. 2010. "If You Are so Smart, Why Aren't You an Entrepreneur? Returns to Cognitive and Social Ability: Entrepreneurs versus Employees.” Journal of Economics and Management Strategy 19:947-89.

Karlan, D., and M. Valdivia. 2010. "Teaching Entrepreneurship: Impact of Business Training On Microfinance Clients and Institutions." Review of Economics and Statistics 93 (2): 510-27.

Kremer, M., J. Lee, J. Robinson, and O. Rostapshova. 2013a. "Behavioral Biases and Firm Behavior: Evidence from Kenyan Retail Shops." American Economic Review, Papers and Proceedings 103 (3): 362-68.

_. 2013b. "The Return to Capital for Small Retailers in Kenya: Evidence from Inventories." Unpublished Manuscript, Harvard University.

McKenzie, D., and C. Woodruff. 2008. "Experimental Evidence on Returns to Capital and Access to Finance in Mexico." World Bank Economic Review 22 (3): 457-82.

Puri, M., and D. Robinson. 2009. "The Economic Psychology of Entrepreneurship and Family Business." Unpublished Manuscript, Duke University.

Rabin, M. 2000. "Risk Aversion and Expected-Utility Theory: A Calibration Theorem." Econometrics 68 (5): 1281-92.

Rauch, A., and M. Frese. 2007. "Let's Put the Person Back into Entrepreneurship Research: A Meta-Analysis on the Relationship between Business Owners' Personality Traits, Business Creation, and Success." European Journal of Work and Organizational Psychology 16:353-85.

Udry, C., and S. Anagol. 2006. "The Return to Capital in Ghana." American Economic Review 96 (2): 388-93.

Van der Sluis, J., M. Van Praag, and W. Vijverberg. (2005). "Entrepreneurship Selection and Performance: A Meta-Analysis of the Impact of Education in Less Developed Countries." World Bank Economic Review 19 (2): 225-61.

World Bank. 2015. World Development Indicators. http://data.worldbank.org/data -catalog/world-development-indicators.

Zhao, H., and S. Seibert. 2006. "The Big Five Personality Dimensions and Entrepreneurial Status: A Meta-Analytical Review." Journal of Applied Psychology 91:259-71. 